\title{
Seroprevalence of Hepatitis B Surface Antigen and Anti-hepatitis C Virus Antibody in a Hospital-Based Population in Ajmer, Rajasthan, India
}

\author{
Payal Mathur, Priyanka Soni Gupta*, Ranveer Singh, \\ Geeta Parihar and Priyam Sharma
}

Department of Microbiology, Jawahar Lal Nehru Medical College and Associated group of Hospitals, Ajmer, Rajasthan, India

*Corresponding author

Keywords

Hepatitis, seroprevalence, Age wise, anti-HCV Ab HBsAg.

\section{Article Info}

Accepted: 28 September 2016 Available Online: 10 October 2016

\section{A B S T R A C T}

Viral hepatitis is a serious public health problem, globally affecting billions of people. A tertiary care hospital in Rajasthan catering to the needs of a large segment of population represents an important center for serological surveys. Limited data is available, at Rajasthan state level, on the seroprevalence of these blood borne pathogens. Serum samples collected over a period of 12 months from January 2015 to December 2015, of patients attending OPDs and admitted to various IPDs of J.L.N.Hospital, Ajmer, were subjected within the hospital-based lab for the detection of HBsAg and anti-HCV Ab using rapid card tests. The seroprevalence was then estimated for both the sexes and different age groups. The seroprevalence of $\mathrm{HBsAg}$ was found to be $0.94 \%$ and of anti-HCV Ab as $0.17 \%$. The $31-40$ age group was affected the most. Males were affected more than females. The study will help in better utilization of public funds for tackling serious public health problems. The regular surveillance \& determination of magnitude of seroprevalence of viral transmission in the community is important for its prevention and control. The study throws light on the seroprevalence of these viral infections in the state of Rajasthan and provides a reference for future studies.

\section{Introduction}

Hepatitis B virus (HBV) and hepatitis C virus (HCV) are among the principal causes of severe liver disease, including hepatocellular carcinoma (HCC) and cirrhosis-related end-stage liver disease.
The World Health Organization (WHO) has estimated that there are 240 million people chronically infected with $\mathrm{HBV}$ (http://www.who.int/mediacentre/factsheets/ fs164/en/). India has been placed into the 
intermediate zone of prevalence of hepatitis B (2-7\% prevalence rates by WHO) (Qamer et al., 2004) (Fig.1). The hepatitis B surface antigen (HBsAg) in serum is the first seromarker to indicate active HBV infection, either acute or chronic (Horvat et al., 2003). Wide variations in the prevalence of hepatitis B has been observed from country to country depending upon a complex mix of various environmental and host factors. In general, it is lowest in countries or areas with high standards of living (e.g., Australia, North America, North Europe) and highest in countries or areas with low socioeconomic Levels (e.g., China, South East Asia, South America). Since 1992 a vaccine is available and has brought marked changes in the global epidemiology of HBV infection.

Hepatitis $\mathrm{C}$ virus infection is a major public health problem especially in developing countries like India. Globally, an estimated $130-170$ million persons $(2 \%-3 \%$ of the world's population) are living with $\mathrm{HCV}$ infection and about 15 million people are living with $\mathrm{HCV}$ infection in India.(Fig.2) Hepatitis $\mathrm{C}$ virus (HCV) causes both acute and chronic infection.

Acute HCV infection is usually asymptomatic, and is only very rarely associated with life-threatening disease. About $15-45 \%$ of infected persons spontaneously clear the virus within 6 months of infection without any treatment. The remaining $55-85 \%$ of persons will develop chronic HCV infection. Of those with chronic $\mathrm{HCV}$ infection, the risk of cirrhosis of the liver is between $15-30 \%$ within 20 years (http://www.who.int/ mediacentre/factsheets/fs 164/en/). HCV infection still remains a burden on the health-care system world-wide with major channels of transmission being related to exposure to blood and blood products. In a developing country the resources to fight the diseases are limited, so the proper assessment of prevalence of the disease helps in the optimal utilization of resources. The government hospitals which caters to all the segments of the society are the logical centres studying the disease prevalence. There are limited studies available on the age and sex related prevalence of hepatitis B and C. Hepatitis C being a preventable disease, its burden can be significantly reduced if its seroprevalence is better known in different age groups. It was against the above backdrop that the present study was undertaken to estimate the seroprevalence of HBs Ag and antibodies to hepatitis $\mathrm{C}$ in both the sexes and different age groups in a hospital-based population in Ajmer, Rajasthan and fill this void in understanding the disease burden in Rajasthan so that the public disease prevention planners could utilize this information to control the disease in the face of financial adversity.

\section{Materials and Methods}

This study was carried out in the Central Laboratory, Department of Microbiology, Jawahar Lal Nehru Hospital, Ajmer, Rajasthan. Patients who registered at the OPDs or were admitted to the IPDs of the hospital and were advised to undergo hepatitis B screening and HCV antibody testing were included in the study. The study extended over a period of 1 year from January 2015 to December 2015 retrospectively. A 5-ml venous blood sample was collected from all the patients who came with lab requisitions for the testing of HBsAg and anti-HCV Ab. The blood was allowed to clot for $45 \mathrm{~min}$ at room temperature and the serum was separated after centrifugation at low speed. The serum sample obtained was then tested for $\mathrm{HbsAg}$ and anti-HCV antibodies. HBsAg was determined using a rapid card method HbsAg Virucheck (Orchid biomedical 
systems ) and anti- HCV antibodies were determined using a rapid card method HCV Tridot (J. Mitra and Company Limited). All the tests were performed in accordance with the manufacturer's instructions with adequate controls.

\section{Results and Discussion}

We report here a retrospective study to assess the epidemiology of HCV and HBV prevalence among the hospital based population in a tertiary care hospital of Ajmer, Rajasthan. A total of 28920 serum samples were processed for $\mathrm{HBsAg}$ detection and 3534 serum samples were tested for hepatitis $\mathrm{C}$ antibodies over the 12month period. Table 1 and 2 show the age and sex distribution of the hospital-based population with hepatitis B \& C seropositivity, respectively. The seroprevalence of HBsAg was found to be $0.94 \%$ and of anti-HCV Ab as $0.17 \%$. The 31-40 age group males were affected more than females with the seroprevalence for HBsAg being $1.12 \%$ and $0.7 \%$ respectively. The highest seroprevalence of anti-HCV was found in males in 11-30 yr age group.

HBV is the second most common cause of acute viral hepatitis after HEV in India. With a $3.7 \%$ point prevalence, that is, over 40 million HBV carriers, India is considered to have an intermediate level of $\mathrm{HBV}$ endemnicity. Every year, one million Indians are at risk for $\mathrm{HBV}$ and about 100,000 die from HBV infection (NCDC newsletter, 2014).

In March 2015, WHO launched its first "Guidelines for the prevention, care and treatment of persons living with chronic hepatitis B infection". In May 2016, The World Health Assembly adopted the first "Global Health Sector Strategy on Viral Hepatitis, 2016-2021". The strategy highlights the critical role of Universal Health Coverage and the targets of the strategy are aligned with those of the Sustainable Development Goals. The strategy has a vision of eliminating viral hepatitis as a public health problem and this is encapsulated in the global targets of reducing new viral hepatitis infections by $90 \%$ and reducing deaths due to viral hepatitis by $65 \%$ by 2030 .

The seroprevalence of HbsAg in our study was found to be $0.94 \%$ in the hospital-based population. Sood \& Malvankar (2010) in their study reported a prevalence of $0.87 \%$. Lodha et al., (2001) in their review article on hepatitis B epidemiology suggested the true prevalence rate in India as $1-2 \%$. There is a wide variation in the prevalence in different regions of our country. In a study conducted in a hospital-based population at Kathmandu Medical College Hospital, Nepal, the prevalence rate of viral hepatitis B was found to be $2.5 \%$ (Bhatta et al., 2003). However, the carrier state of HBsAg is defined as persistence of this antigen in the blood for over 6 months. Thus, a single determination of HBsAg done on the patients may not be the ideal way of defining the carrier state.

Despite the large number of young adults in $<20$ group tested (3252males \& 2424 females) only $31(0.54 \%)$ were positive for HBsAg. These results indicate that the strong efforts made among younger generation have had some success with the introduction of $\mathrm{HBV}$ infant vaccination since 1992 and its integration into the national immunization program in 1999, in addition, hepatitis B Ig and HBV vaccine treatment for newborns of $\mathrm{HBV}$-infected mothers at delivery could also contribute to the significant reduction. Maximally affected were males in the age group of 3140 years. 
Gender analysis reveals significantly higher hepatitis B seroprevalence among males as compared to females in our study accounting to $1.12 \%$ and $0.7 \%$ respectively; this data was comparable to other reports (Dutta et al., 1994). There has been no plausible explanation for the higher rate in males in the general population but probably due to the higher exposure to occupational HBV risk factors in men but also probably because females clear the $\mathrm{HBV}$ more efficiently as compared to males.

The presence of anti-hepatitis $\mathrm{C}$ virus antibody indicates previous exposure to hepatitis $\mathrm{C}$ virus. This antibody is present in only $40 \%$ of acute infections but in more than $95 \%$ of chronic infections (Baheti, 2000). The population prevalence of $\mathrm{HCV}$ infection in India is $1 \%$ and the estimated burden of chronic HCV infections in South Asia is 50 Million.

Table.1 Age and sex distribution of the hospital-based population

with hepatitis B seropositivity $(n=28920)$

\begin{tabular}{|c|c|c|c|c|c|}
\hline Age(Years) & $\begin{array}{c}\text { No. of } \\
\text { males } \\
\text { tested }\end{array}$ & $\begin{array}{c}\text { No.of } \\
\text { females tested }\end{array}$ & $\begin{array}{c}\text { No. of males } \\
\text { with HbsAg } \\
\text { detected }(\%)\end{array}$ & $\begin{array}{c}\text { No.of females } \\
\text { with HbsAg } \\
\text { detected }(\%)\end{array}$ & $\begin{array}{c}\text { Total HbsAg } \\
\text { positive cases } \\
(\%)\end{array}$ \\
\hline $0-10$ & 1464 & 732 & $5(0.34)$ & $5(0.7)$ & $10(0.45)$ \\
\hline $11-20$ & 1788 & 1692 & $15(0.83)$ & $6(0.35)$ & $21(0.6)$ \\
\hline $21-30$ & 3456 & 2448 & $38(1)$ & $23(0.93)$ & $61(1)$ \\
\hline $31-40$ & 2508 & 2004 & $59(2.35)$ & $23(1.14)$ & $82(1.8)$ \\
\hline $41-50$ & 2268 & 1380 & $34(1.5)$ & $8(0.6)$ & $42(1.15)$ \\
\hline $51-60$ & 3228 & 2112 & $26(0.8)$ & $5(0.23)$ & $31(0.58)$ \\
\hline$>60$ & 2484 & 1356 & $17(0.7)$ & $8(0.6)$ & $25(0.65)$ \\
\hline Total & 17196 & 11724 & $194(1.12)$ & $78(0.7)$ & $272(0.94)$ \\
\hline
\end{tabular}

Table.2 Age and sex distribution of the hospital-based population with anti-HCV Ab seropositivity $(\mathrm{n}=3534)$

\begin{tabular}{|c|c|c|c|c|c|}
\hline Age(Years) & $\begin{array}{c}\text { No. of } \\
\text { males tested }\end{array}$ & $\begin{array}{c}\text { No. of females } \\
\text { tested }\end{array}$ & $\begin{array}{c}\text { No. of males with } \\
\text { anti HCV Ab } \\
\text { detected }(\%)\end{array}$ & $\begin{array}{c}\text { No.of females with } \\
\text { anti HCV Ab } \\
\text { detected (\%) }\end{array}$ & $\begin{array}{c}\text { Total anti HCV } \\
\text { Ab positive } \\
\text { cases (\%) }\end{array}$ \\
\hline $0-10$ & 10 & 05 & $00(0)$ & $00(0)$ & 00 \\
\hline $11-20$ & 59 & 21 & $02(3.3)$ & $00(0)$ & 02 \\
\hline $21-30$ & 126 & 94 & $01(0.8)$ & $01(1)$ & 02 \\
\hline $31-40$ & 303 & 201 & $01(0.33)$ & $00(0)$ & 01 \\
\hline $41-50$ & 295 & 271 & $00(0)$ & $00(0)$ & 00 \\
\hline $51-60$ & 595 & 371 & $00(0)$ & $01(0.27)$ & 01 \\
\hline$>60$ & 778 & 405 & $00(0)$ & $00(0)$ & 00 \\
\hline Total & 2166 & 1368 & $04(0.18)$ & $02(0.15)$ & $06(0.17)$ \\
\hline
\end{tabular}


Fig.1 Global endemicity to HBV infection; darker shades suggest areas with greater seroprevalence of HBV. (4)

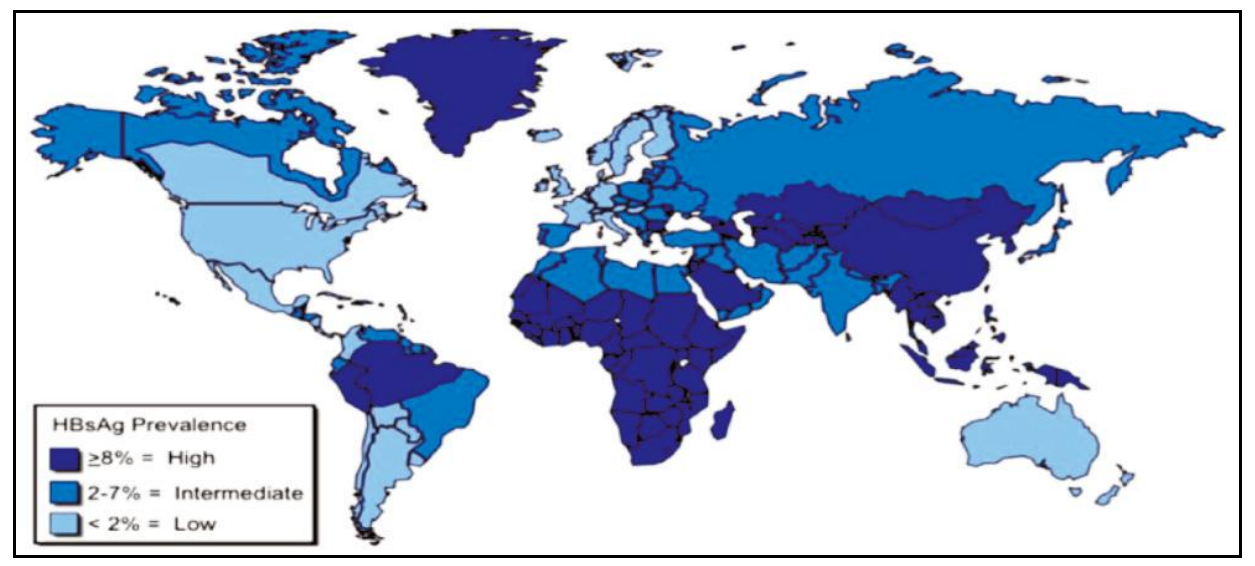

Fig.2 Global endemicity to HCV infection; darker shades suggest areas with greater seroprevalence of $\mathrm{HCV}(\%) .(4)$

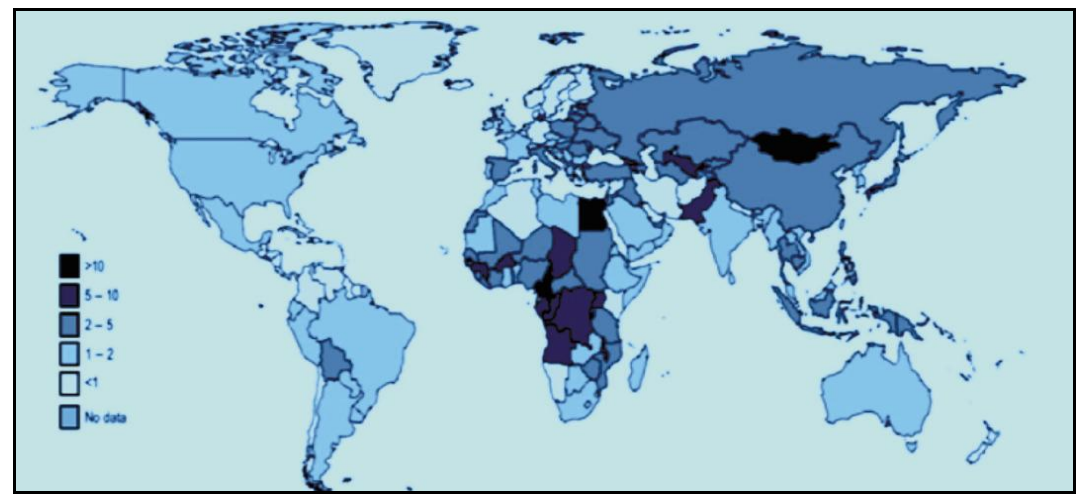

The seroprevalence of $\mathrm{HCV}$ among our hospital-based population was found to be $0.17 \%$. This seroprevalence is echoed in studies done by Sood \& Malvankar \& Pahuja et al., (2007) where the seroprevalence was $0.28 \%$ \& $0.66 \%$ respectively, but its much lower than the $1.7 \%$ seroprevalence reported in an earlier study from Jaipur (Rajasthan) in 2007 by Sharma et al., (2007). In India, the seroprevalence of HCV varies among hospital-based populations with $1.57 \%$ reported from Cuttack (Orissa), (Mishra et al., 2002) $4.8 \%$ from Pondicherry, (Bhattacharya et al., 2003) and $2.46 \%$ from Jodhpur (Rajasthan).
In the present study the six cases reactive for $\mathrm{HCV}$ antibodies belonged to age groups 1120 years and 20-30 years mainly while one case each in 31-40 and 51-60 years age groups. The small sample size of reactive cases in our study does not allow data to be compared with other reports. The comparatively high prevalence seen in young adults (15-40 years)can be due to unsafe injecting practices, intravenous drug abuse and unsafe sex practices all of which contribute to the increased overall seroprevalence of HCV (EASL, 1999). Tattooing could be an added risk factor (Nishioka et al., 2001). 
To the best of our knowledge this is the first report defining rates of infection with these bloodborne agents among the hospital-based population in Ajmer, Rajasthan. The observed rates likely reflect the patient population served by our hospital and do not necessarily apply to other centers. However, the study does throw light on the dynamics of viral transmission in the community in this part of the country and provides a good reference for future studies because of the large number of cases investigated.

The study estimates the seroprevalence of $\mathrm{HBV}$ and $\mathrm{HCV}$ in Ajmer, Rajasthan and extrapolates the data to estimate the disease burden of HBs $\mathrm{Ag}$ and $\mathrm{HCV}$ in both the sexes and different age groups in a hospital based population. The study indicates that HBV infection is still a public health problem which should be among the prioritized health problems in the country. It is necessary that medical and health-care personnel are educated about the dangers and consequences of $\mathrm{HCV}$ infections. Considering the asymptomatic nature of the infection and its potentially lethal consequences, all blood donors and bloodproduct recipients must be screened for anti$\mathrm{HCV} \mathrm{Ab}$. The scarcity of data and the degree to which they are out of date were the main reasons behind this survey, aimed to determine the prevalence of $\mathrm{HCV}$ and $\mathrm{HBV}$ infections to unravel the true status of viral hepatitis and thus provide valuable information about surveillance and estimation.

\section{References}

Baheti, R., Gehlot, R.S., Baheti, R. 2000. Seroprevalence of anti $\mathrm{HCV} \mathrm{Ab}$ in healthy voluntary blood donors and in high risk individuals. JIACM, 1: 2302.
Bhatta, C.P., Thapa, B., Rana, B.B. 2003. Seroprevalence of Hepatitis B in Kathmandu Medical College Teaching Hospital. Kathmandu Univ. Med. J., (KUMJ), 1: 113-6.

Bhattacharya, S., Badrinath, S., Hamide, A., Sujatha, S. 2003. Seroprevalence of hepatitis $\mathrm{C}$ virus in a hospital based general population in South India. Indian J. Med. Microbiol., 21: 43-5.

Dutta, S., Shivananda, P.G., Chatterjee, A. 1994. Prevalence of hepatitis B surface antigen and antibody among hospital admitted patients in Manipal. Indian J. Public Health, 38: 108-112.

EASL International Consensus Conference on hepatitis C. Paris, 26-27 February 1999. Consensus statement. J. Hepatol., 31 Suppl 1: 3-8.

Horvat, R.T., Tegtmeier, G.E. 2003. Hepatitis B and D viruses. Manual of Clinical Microbiology. In: Murray PR, Baron EJ, Jorgensen JH, Pfaller MA and Yolken R H. editors. Washington D.C: ASM Press; 2003. p. 1464-78.

http://www.who.int/mediacentre/factsheets/f s164/en/

Lodha, R., Jain, Y., Anand, K., Kabra, S.K., Pandav, C.S. 2001. Hepatitis B in India: $A$ review of disease epidemiology. Indian Pediatr., 38 : 1318-22. (PubMed)

Mishra, S., Chayani, N., Sarangi, G., Mallick, B., Pati, S.B. 2002. Seroprevalence of anti HCV antibody in and around Cuttack, Orissa. Indian J. Med. Microbiol., 20: 40-1.

NCDC newsletter. 2014. Hepatitis in India: Burden, Strategies and Plans, Volume 3 , Issue 1 .

Nishioka, S., Gyorkos, T.W. 2001. Tattoos as risk factors for transfusiontransmitted diseases. Int. J. Infect. Dis., 5: 27-34.

Pahuja, S., Sharma, M., Baitha, B., Jain, M. 2007. Prevalence and trends of 
markers of hepatitis $\mathrm{C}$ virus, hepatitis $B$ virus and human immunodefi ciency virus in Delhi blood donors: A hospital based study. Jpn. J. Infect. Dis., 60: 389-91.

Qamer, S., Shahab, T., Alam, S., Malik, A., Afzal, K. 2004. Age specific prevalence of Hepatitis B surface antigen in pediatric population of Aligarh, North India. Indian $J$. Pediatr., 71: 965-7.
Sharma, R., Sinha, P., Bachiwal, R., Rishi, S. 2007. Seroprevalence of Anti hepatitis $\mathrm{C}$ virus antibodies in a hospital based population in Jaipur, Rajasthan. Indian J. Community Med., 32: 158-9.

Sood and Malvankar. 2010. Seroprevalence of $\mathrm{HBsAg}$, anti-HCV $\mathrm{Ab}$, and antiHIV Ab. Indian J. Community Med., 35(1): 165-169.

\section{How to cite this article:}

Payal Mathur, Priyanka Soni Gupta, Ranveer Singh, Geeta Parihar and Priyam Sharma. 2016. Seroprevalence of Hepatitis B Surface Antigen and Anti-hepatitis C Virus Antibody in a Hospital-Based Population in Ajmer, Rajasthan, India. Int.J.Curr.Microbiol.App.Sci. 5(10): 1023-1029. doi: http://dx.doi.org/10.20546/ijcmas.2016.510.108 